\title{
リング精紡, 撚系機の卷取りについで
}

（第 2 報）紡出番手とトラベラ番手の関係

(昭和 29 年 4 月 7 日受理) 会員藤野清 久

”三浦義少

\begin{abstract}
研 究 目 的
紡出番手に応じてトラベラ番手は一応定められているが, 計算上からこれらの関係を求めて，任意番手紡出の際
に使用すへきトラへラを推定する場合の目安とした。
\section{研 究 結 果}

ある紡出番手の系に適するトラベラ番手が経験的に分ると, 同一寸失のリンクを用いたものては, 他の紡出番手 用のトラヘラ番手を計算上求めることが出来た.

即ちハルーニンクしている系の張力の垂直分力を $T$, 系の番手を $N_{e}$ とすると $T N_{e}=$ 一定 の関係か望ましい. 故任意の $N_{e}$ のときの $T$ からトラベラ番手を知り得る. 計算上から求めたすのと従来の経験的なすのとは大体 啇合しているので，一応使用すべきトラベラを仭定する目安になると思う。
\end{abstract}

\section{1. 緒}

\section{論}

ソンク精紡，撚糸機等に使用されるトラベラの番手は 紡出糸の番手飞適当したものを選ばねばならない. 現在 用いられているすつは経験的に求められたものと思われ る・トラヘラの重さは次の事項を考慮して定めねばなら ない。

（1）セバレータにバルーンが接触せず, 又セパレー タが血い場命はハルーン同志が接触しないよう飞調節す る・リンクレールがホヒンの底部近くにあって鞅管近い とき最め接触し易い。

（2）ハルーンがホヒンの頭部に接触しないように調 節する・ホヒン底部の位置て卷き始めのときが最す接触 し易い。

（3） 米の張力は系層及ひトラハースの変化に応じて 変わるが, 最大張力のとき飞切断しないように調節す る.

（4） 2 本引揃え粗系を紡出する場合には, その内の 1 本が切断して糸の張力が異常に弱くなったとき残りの 系す切断するよう調節する。

（5） ホヒンに卷かれた糸玉が崩れない程度の堅さに 卷けるような張力を与えるようと調節する。
以上の事柄を考慮してある番手の彎当したトラヘ ラが决ってい尚場今に, 他の番手の杀を紡出するに適し たトラヘラ番手を計算上求 め,乙れを経験上から仭っ ているものと比較して見よ 亏.

\section{2. パルーンの形狀}

ハルーンの計算は普通用 いられているすのに従って 計算する.

宾気抗力を無視したハル ーンで,第1図のようにス ネルワイヤO から $y$ 方 向飞 $h$ 隔てて半径 $R$ のv ンクがある.糸の单位長当

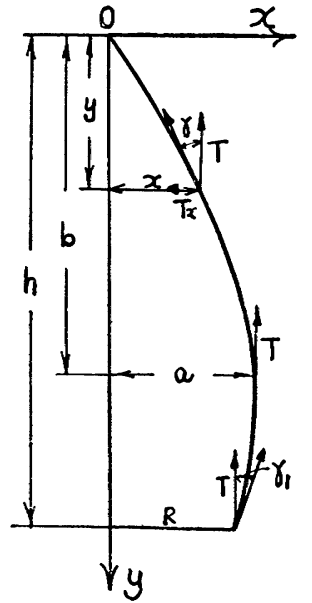

（第 1 凶） 糸の張力分布
りの質量 $\rho$ は $y$ 方向飞一様であると仮定して, $(x, y)$ 飞打ける糸の質量 $\rho d y$ が持つ遠心力 $d C$ は

$$
d C=\rho d y x \omega^{2} \quad \text { 但し } \omega \text { はトラベラの角速度 }
$$
糸の $y$ 方向の張力の分力を $T, x$ 方向の分力を $T_{x}$, $y$ 軸対する傾科角を $\gamma$ とすれば

* Studies on Yarn Winding on Ring Frames. (Part 2) : Rflation between Yarn Counts and Traveller Counts.

*\% K. Fujıno, Member. 京都大学

Y. Miura, " 京都工藝瀻雄大学 


$$
T_{x}=T \tan \gamma=T \frac{d x}{d y}
$$

$T$ はバルーン上の位置に拘らわらず一定, $T_{x}$ は糸の遠 心力と釣合うょうにバルーンの形状が決定されるから

$$
T \frac{d x}{d y}=\int_{y}^{b} \rho x \omega^{2} d y
$$

但しバルーンの最大膨らみ点の座標を $(a, b)$ とする.

$$
\therefore \frac{d^{2} x}{d y^{2}}=-\frac{\rho \omega^{2}}{T^{\prime}} x
$$

この微分方程式の解は正弦函数である。即ち $x$ を( 3 ) 式のように置く.

$$
\begin{aligned}
& x=a \sin k y \ldots \ldots \ldots \ldots \ldots \ldots . . . \\
& \frac{d x}{d y}=a k \cos k y \quad \ldots \ldots \ldots \ldots . \\
& \frac{d^{2} x}{d y^{2}}=-a k^{2} \sin k y=-k x
\end{aligned}
$$

従って

$$
k=\sqrt{\frac{\rho \omega^{2}}{T}}
$$

綿，スフ糸の英式番手を $N e$ とすれば

$$
\rho=\frac{453.6}{76810 N_{e} g}=6.03 \times 10^{-6} \frac{1}{N_{e}}
$$

又トラベラの回転数を $\boldsymbol{n}$ (r.p.s.) とすれば

$$
\omega=\frac{\pi n}{30}
$$

$$
\therefore \quad k=2.57 \times 10^{-4} \frac{n}{\sqrt{T N_{e}}} .
$$

バルーン最大膨らみの点 $(a, b)$ では

$$
\sin k b=1 \quad \therefore k b=\frac{\pi}{2}
$$

従って

$$
b=\frac{\pi}{2 k}=6.1 \times 10^{3} \frac{\sqrt{T N_{e}}}{n}
$$

バルーンのリング周上の点 $(R, h)$ では

$$
R=a \sin (\pi-k h)=a \sin \left(\pi-\frac{\pi h}{2 b}\right)
$$$$
\therefore \quad a=\frac{R}{\sin \left(\pi-\frac{\pi h}{2 b}\right)}=\frac{R}{\sin \left(\pi-\frac{2.57 \times 10^{-4} h n}{\sqrt{T N_{e}}}\right)}
$$

この点に招けるバルーン外形の垂直線に対する傾斜角 を $\gamma_{1}$ とすれば

$$
\tan \gamma_{1}=a k \cos k h
$$

(7), (8) 式と上式加

$$
\tan \gamma_{1}=2.57 \times 10^{-4} \frac{n R}{\sqrt{T N_{e}}} \cot \left(2.57 \times 10^{-4} \frac{n h}{\sqrt{T N_{e}}}\right)
$$

第 2 図に括いて $C$ 懫量 $G$ のトラベラの遠心力で

$$
C=\frac{G R}{g}\left(\frac{\pi n}{30}\right)^{2}=1.12 \times 10^{-5} G R n^{2}
$$

$P$ をトラベラとボビン間の糸の張力， $\boldsymbol{\beta}$ を糸がトラベ ラとスピンドル中心とを結ぶ線に対してなす角とすると

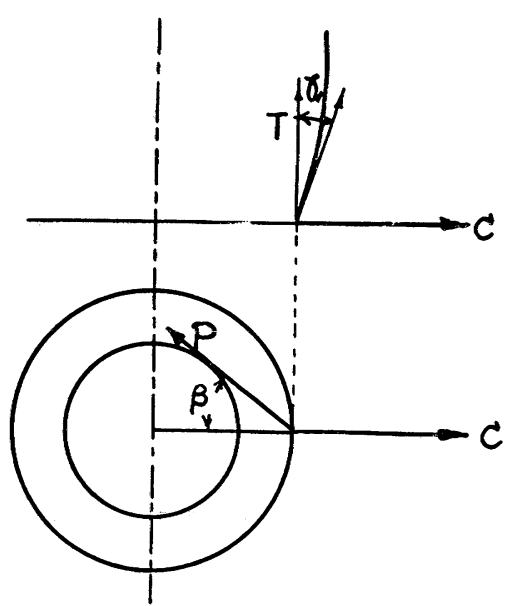

(第 2 図) 糸の張力分布

$$
P \sin \beta=\mu \sqrt{T^{2}+\left(C+T \tan \gamma_{1}-P \cos \beta\right)^{2}}
$$

但し $\mu$ はンングとトラベラとの摩擦係数

$P$ と $T / \cos \gamma_{1}$ との関係は両者の夾角を $\theta$, トラベラと 系との摩擦係数を $\mu^{\prime}$ とすると

$$
\begin{aligned}
& P=\frac{T}{\cos \gamma_{1}} e^{\mu^{\prime}(\pi-\theta) \ldots} \\
& \cos \theta= \pm \sin \gamma_{1} \cos \beta
\end{aligned}
$$

(13) 式に招いて， $\theta>\frac{\pi}{2}$ のとき右辺山負， $\theta<\frac{\pi}{2}$ の とき正である. (9)，(11)，(12)，(13)の4式から $\gamma_{1}$ $\theta, P, T$ の值が求められる。即ち（9）式老

$$
f_{1}\left(\gamma_{1}, T\right)=0
$$

(11), (12), (13) 各式と（10）式から

$$
f_{2}\left(\gamma_{1}, T\right)=0
$$

\section{3. $N_{e}$ と $G$ との関係}

20 's 綿杀用トラベラの重さを $0.0583 \mathrm{~g}$ どする.

今スピンドルの回転数を 9000 r.p.m. としてトラベラ の回転数をその $1 \%$ 減とすれば $n=8.910$ r.p.m., $R=$ $2.06 \mathrm{~cm}, r=1 \mathrm{~cm}, h=20 \mathrm{~cm}, \mu=0.2, \mu^{\prime}=0.3$ の数值

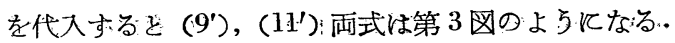
故长第3园加ら $\gamma_{1}=0.265, T=19 \mathrm{~g}$ を得る。

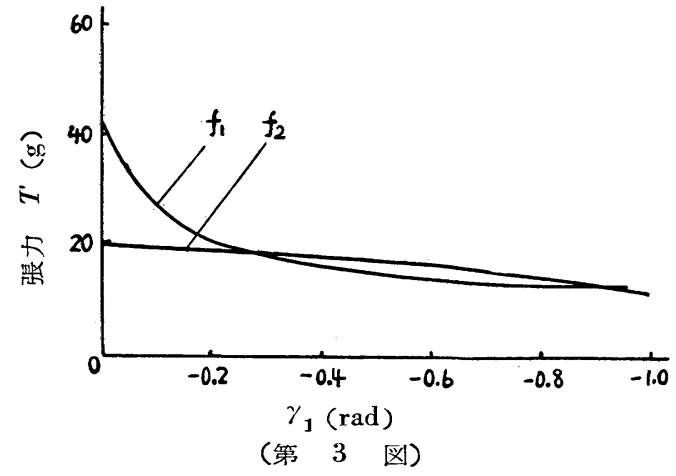


同一機で各種番手の糸を精紡又は撚系するには糸の番 手に拘わらずバルーンの形状が一定であることが望まし い. 即ち(9)式打いて $\gamma_{1}$ が一定なるためとは $\sqrt{T N_{e}}$ が一定となる・数值を代大すると

$$
T N_{e}=19 \times 20=380
$$

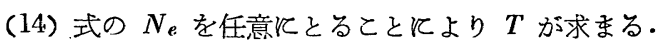

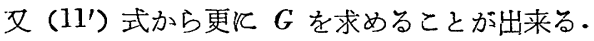

紡出番手とトラベラ番手（質量に換算しための）との 関係を第 4 図江示した. 図中実線は経験的に使用されて いるすのであり, 点線は計算值である。な拊の例をと ると $20^{\prime}$ s 綿糸を紡出する際リング径住応じてトラペラ 番手を変えていることは第1 表の通りである。

（第 1 表）リング径別によるトラベラ種類

\begin{tabular}{c|c|c|c}
\hline \hline リング直径 (in) & $1 \frac{1}{2}$ & $15 / 8$ & $13 / 4$ \\
\hline トラベラ 番 手 & 3 & 2 & 1 \\
\hline トラベラ重さ (g) & 0.0778 & 0.0713 & 0.0558 \\
\hline
\end{tabular}

リングとトラベラ以外は前述の数值をとのまま使用し たときの $N_{e}$ と $G$ との関係を第5 図に示した.

図中 $A, B, C$ はリング径がそれぞれ $1 \frac{1}{2}, 15 \%$, $13 / 4$ in の場合で, 実線は経験値, 点線は計算值を示す.

以上第 4,5 図から大体計算值と経験值とが近似して いるととが分っ：特第4図で注 30 ：40's 附近を除い てはよく適合し，第 5 図では同一番手の綿糸でも綿花の 種類に応じてトラベラの番手に3〜4番の変動があると されているので, これを考慮するとほぼ適合するすのと みなされる。

\section{4. 結論}

紡出番手に適するトラベラの大きさは経騃的に求めら れている。

同一リングを用いて番手の違った糸を紡出する上に適 当なトラベラを計算上求め, 経験的事実と比較した.

即ちある番手の糸滴するトラベラが経験的に分って 招れば, その場合の糸張力の垂直分力 $T$ を求め 糸の 英式番手を $N_{e}$ とすれば $T N_{e}=$ 一定の関係が望ましい これを利用して任意糸番手に対する $T$ の値を知り, 或 はトラベラ番手を決めることが出来る.

これら一連の研究は文部省科学試験研究費の援助を得 たものである.

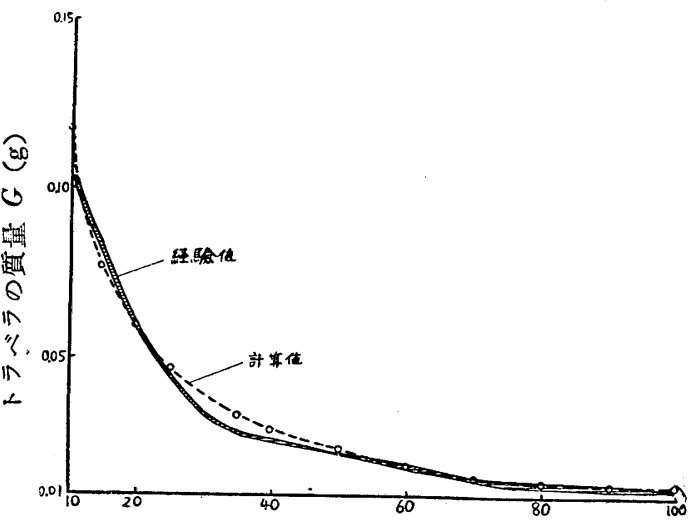

紡出番手 $N_{e}($ ('s)

（第4図）紡出番手とトラベラ質量との関係
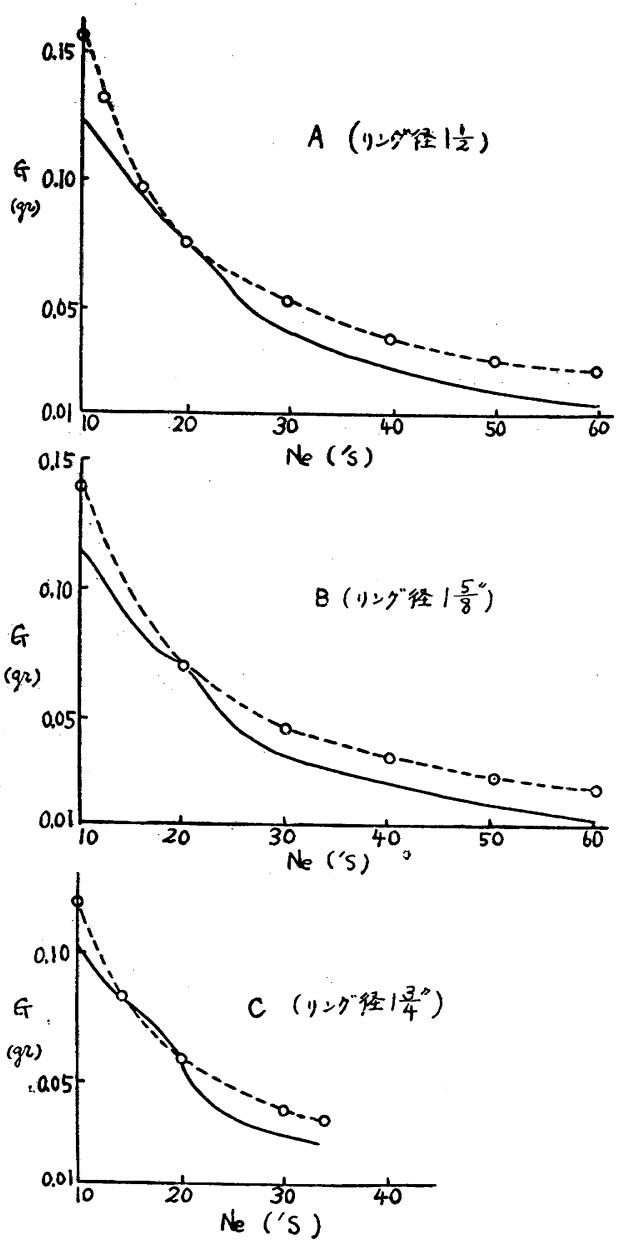

（第 5 図）紡出番手とトラベラ質量との関係 （実線は経験值，点線は計算值）

\section{文献}

1) 纎維機械, 第 1 巻, P. 162

2）最新綿系紡績学, P. 230 